\title{
Social Support, Negative Affectivity, and Work Personal Life Balance of Academics
}

\author{
Siti Asiah Md. Shahid, Suhaiel Amdan, Anisah Alwi, Farah Syazreena, and Che Norlia Hassan
}

\begin{abstract}
This study explores the relationship between social support, negative affectivity, and work-personal life balance among academic staff. The sample of this study comprised $\mathbf{7 0}$ academics at one faculty in one public higher educational institution in Perak, Malaysia. Quantitative research design using survey questionnaires was utilized for this study. Findings indicated that work-personal life balance is significantly related with social support and negative affectivity. In addition, social support from co-workers is the most significant predictor for work-personal life balance.
\end{abstract}

Index Terms-Social support, negative affectivity, work-personal life balance, academics, higher educational institution.

\section{INTRODUCTION}

Two important domains of one's life are work and family. Balancing work and personal life roles has always been an important issue and concern for organizational employees globally and among academics in higher education institution [1]. Technological changes in the workplace such as smart phones for work-based activities have afforded academics to work outside legal working hours, thus, giving an impact on the academics work-personal life balance. In addition, increased demand in the academics work roles and responsibilities such as administrative work, quality research and teaching, publication, supervision, innovation, producing high quality graduates and so forth, has made it difficult for them to meet their social, family, and work obligations efficiently. These multiple work roles of university academics have increased their working hours and have also influenced their perceived personal work-life balance such as job satisfaction and physical health. According to [2] balancing a successful career with personal or family life can be challenging and can impact on people's satisfaction in their roles in work and personal life. The academic profession is one of the most stressful occupations that can affect mental and physical health. Therefore, university management needs to provide the necessary support to increase the academics' productivity and quality of teaching, thereby producing a positive effect overall.

Manuscript received November 25, 2014; revised March 5, 2015.

Siti Asiah Md. Shahid is with the Institute of Business Excellence, University Technology MARA Shah Alam, 40450 Shah Alam, Selangor Darul Ehsan, Malaysia (e-mail: sitia348@puncakalam.uitm.edu.my).

Suhaiel Amdan, Anisah Alwi, Farah Syazreena Azmi, and Che Norlia Hassan are with the Faculty of Business Management, University Technology MARA Shah Alam, 40450 Shah Alam, Selangor Darul Ehsan, Malaysia (e-mail: anisah@puncakalam.uitm.edu.my, suhaie12013@gmail.com norlia361@puncakalam.uitm.edu.my).

\section{LITERATURE REVIEW}

Work-personal life balance is a comfortable state of equilibrium achieved between an employee's primary priorities of his or her employment position and his or her private lifestyle. Most scholars define work-personal life balance as a feeling of accomplishment and satisfaction regarding work and life beyond work. According to [3] good physical health can contribute to work-personal life balance. Furthermore, [3] argues that work-personal life imbalance affects the overall well-being of the individual causing problems such as dissatisfaction from life and prolonged sadness. The achievement of good work-life balance can yield benefits for employers in terms of having a more motivated, productive, and less stressed workforce that feels valued. Similarly, [4] emphasized that work-life balance must be supported and encouraged at all levels of the organization, including senior management, line managers and all staff. Consistently, the importance of work-personal life balance is supported by research and literatures, which indicate that good work-personal life balance is important to effective worker performance. However, recent research by Hay Group indicated that $39 \%$ of employees did not have a good balance between work and personal life. In addition, one in four employees working at organizations that are perceived as not supporting work-life balance, plan to leave their companies within the next two years.

One of the important elements that contribute to work -personal life balance is social support. Social support is the perception and actuality of the people who are caring towards one another and are getting assistance available from other people. These supportive resources can be tangible such as personal advice or companionship. Besides that, social support from supervisors and co-workers are found to be important contributors to work-personal life balance, work-family conflict, job satisfaction, and health [5]. Similarly [6] found that when supervisors enthusiastically support the integration of paid work and other responsibilities, employees are better able to utilize available work-personal life balance options. Thus, the positive mood that supervisors and co-workers create at the workplace can lead to job satisfaction which directly helps employees to have a better work-personal life balance. Consistently, [7] emphasized that social support from supervisors and co-workers provides resources for fulfilling role of responsibilities. These two sources of social support are likely to help individuals cope with stressors. In addition, each type of social support may lead to an overall level of satisfaction with the exchange between work and personal life. 
On the other hand, working may result in negative affectivity when there is not enough rest, packed worked hour, and heavy workload. According to [8] negative affectivity is a general dimension of subjective distress and unpleasurable mood. It is considered as negative affectivity when employees experience negative effect that resulted from their environment. In relation to that [9] found that negative affectivity moderated the connection between job stress and work-family conflict. Studies have also indicated that negative affectivity elements such as distress, hostility, irritability and so on decrease the happy mood of employees and can lead to job dissatisfaction.

In addition, work-personal life balance is concerned with the benefits that employers provided to their employees. It is related to career and lifestyle as in guiding people when to stop working and moving on to other aspects of life. Moreover, work-personal life balance is also about adjusting working patterns to allow employees to combine work with other responsibilities such as caring for children or elderly relatives as suggested by [10]. He further said that having balance between work and life helps employees to achieve a better work-life. Furthermore, it enables employees to feel more in control of their working life and can lead to increased productivity, lower absenteeism and a happier, less stressed workforce. Hence, it is important for university academics to allocate their energy respectively and equally, so as to have time for relaxing and recharging.

Background of this study is based on social support, negative affectivity, and work-personal life balance. The two components of social support are supervisors and co-workers. In this study social support from supervisors means that supervisors can be relied on when things get tough at work. Supervisors are willing to listen to work-related problems. They help employees to get their done. Finally, they are willing to listen to personal problems. These four items similarly apply for co-workers. In addition, negative affectivity refers to the extent to which respondents experience negative affect which include getting distressed, upset, guilty, hostile, irritable, ashamed, nervous, jittery, and afraid. Work-personal life balance refers to the extent to which respondents are satisfied with their jobs, like their jobs like working at their organization and attain their overall physical health.

As stated by [11] a successful educational institution depends on the level of satisfaction of its staff. Additionally, quality of teaching cannot be achieved without highly satisfied teachers [12]. Hence, this study on social support, negative affectivity, and work-personal life balance would provide greater insights on these issues.

\section{RESEARCH QUESTIONS}

This study seeks to answer two research questions:

1) Is there is a significant relationship between social support, negative affectivity, and work-personal life balance?

2) What are the most significant predictors for personal work-life balance?

\section{Methodology}

This study utilised a survey research design using quantitative method. Data were collected using survey questionnaires distributed to academics at one public university from one faculty in Perak, Malaysia. On 14 October 2013, 86 questionnaires were distributed to the respondents. The respondents were given two weeks to complete the questionnaires. Finally, 70 of them completed the questionnaires yielding a response rate of 80 percent. To expedite the return of the questionnaires, follow-up emails were sent to the respondents.

The questionnaire consisted of 29 questions (including demographic items). An 8-item survey adapted from Caplan, Cobb, French, Van Harrison, and Pinneau was used to measure social support from supervisors and co-workers. Respondents negative affectivity was measured with 9 items of positive and negative affect schedule (PANAS) subscale developed by Watson et al. Work- personal life balance which is related to job satisfaction and physical health were measured using 4 items. Job satisfaction was measured using 3 items from Michigan Organizational Assessment Questionnaire while individual physical health was measured with 1 item adapted from Frone et al.

In addition, 7-item question was designed to obtain information about the demographics of the respondents such as age, gender, marital status, level of education, length of service, current employment status, and number of hours work per week.

\section{RESUlts}

\section{A. Sample Description}

The data obtained from the completed questionnaires were analysed using SPSS version 21. Respondents of this study consisted of academics from one public university from one faculty. With respect to the level of education, all the respondents had Master's Degree. This is understandable because it is the entry level of education for academics in both public and private universities in Malaysia. With regard to employment status, all the respondents were permanent staff. Most of the respondents were females (55.7\%) while only $44.3 \%$ of them were males. This is because in general, female are more interested in the teaching field. The demographic data indicated that most of the respondents were married $(85.7 \%)$ while $14.3 \%$ of the respondents have reported as unmarried. Furthermore, 44 of the respondents $(62.9 \%)$ had children, while only 26 of them (37.1\%) did not have children. Majority of the respondents (40\%) were in the $31-40$ years age group category, followed by $31.4 \%$ who were in the 30 years or less age group. In addition, $23.9 \%$ of the respondents were in the 41-50 age group. The smallest proportion of respondents $(4.7 \%)$ was from the age group of 51-60 years old. This demographic data is consistent with the respondents' years of service as majority of them have been working with their organization for more than 11 years. In addition, majority of the respondents (69\%) worked for 41 to 50 hours per week, while $31 \%$ of the respondents work between 61-70 hours per week. None of the respondents worked less than 41 hours per week as this is the job 
requirement for university academics.

\section{B. Correlation between Variables}

This section discusses the findings on the correlation between social support, negative affectivity, and work -personal life balance. Table I shows, the interpretation of the correlation coefficients.

TABLE I: DESIGNATION OF STRENGTH OF ASSOCIATION BASED ON SizE OF CORRELATION COEFFICIENTS

\begin{tabular}{lcc}
\hline \multicolumn{1}{c}{ Strength of Association } & Negative & Positive \\
\hline Weak & -0.29 till -0.10 & 0.10 till 0.29 \\
Moderate & -0.49 till -0.30 & 0.30 till 0.49 \\
Strong & -1.00 till -0.50 & 0.50 till 1.00 \\
\hline \hline
\end{tabular}

Source: Cohen (1988)

\section{Correlation between Social Support, and \\ Work-Personal Life Balance}

Pearson product-moment correlation was used to ascertain the relationship among variables in this study. Results displayed in Table II show that the correlation between all the components of social support and work-personal life balance were significant $(p<.01)$, weak to moderate, and positive (Table I). Moving on to Table II, work-personal life balance was significant, positive, and had a weak correlation with social support from supervisor $(r=.107 ; p<.01)$ and a moderate relationship with social support from co-workers $(r$ $=.371 ; p<.01)$. These coefficients show that an improvement in social support from supervisor is associated with an improvement in the academics' work-personal life balance. In addition, the results also indicated that an improvement in social support from co-workers was moderately associated with an improvement in the academics' work-personal life balance. Overall the correlation between social support and work personal life balance were moderate, positive, and significant ( $r=.301 ; p$ $<$.01). In summary, social support from co-workers were moderately correlated with work-personal life balance $(r$ $=.371 ; \mathrm{p}<.01)$, while social support from supervisor had the weakest relationship $(r=.107 ; p<.01)$.

TABLE II: CORRELATION COEFFICIENTS BETWEEN THE TWO COMPONENTS OF SOCIAL SUPPORT AND WORK PERSONAL LIFE BALANCE

Components of Social Support Pearson Correlation Coefficient $(r)$

$\begin{array}{ll}\text { Supervisor } & .107 * * \\ \text { Colleagues } & .371^{* *} \\ \text { Overall Social Support } & .301 * *\end{array}$

*** Significant at .01

TABLE III: CORRELATION COEFFICIENTS BETWEEN NEGATIVE AFFECTIVITY AND WORK - PERSONAL LIFE BALANCE

Pearson Correlation Coefficient $(r)$

Negative Affectivity .303

Significant at .01

\section{Correlation between Negative Affectivity and} Work-Personal Life Balance

Results in Table III show that the correlation between negative affectivity and work-personal life balance were significant, positive, and moderate $(r=.303 ; p<.01)$. This implies that an improvement in negative affectivity is moderately associated with an improvement in work-personal life balance.

\section{E. Significant Predictor(s) for Work Personal Life Balance}

A stepwise regression analysis was conducted to identify the significant predictor(s) for work-personal life balance. Results in Table IV indicated that the most important predictor for this regression model was co-workers $(B=.371$, $P<.01)$ implying that only one variable has an impact on work-personal life balance. The adjusted $R^{2}$ being .120 showed that the impact of co-workers on work-personal life balance was $12 \%$. In conclusion, social support from co-workers accounted for $12 \%$ of the variation in the dependent variable.

TABLE IV: ESTIMATED REGRESSION EQUATION TO DETERMINE PREDICTORS OF WORK - PERSONAL LIFE BALANCE

\begin{tabular}{lccc}
\hline \hline VARIABLE B B & $R$ & $\begin{array}{c}\text { ADJUSTED } \\
R^{2}\end{array}$ & $\begin{array}{c}\text { ADJUSTED } R^{2} \\
\text { Change }\end{array}$ \\
\hline CONSTANT 3.253 - & & - \\
& & & - \\
$\begin{array}{l}\text { Social Support .285 .371 } \\
\text { (Coworkers) }\end{array}$ & 71 & .120 & .120 \\
\hline \hline
\end{tabular}

\section{DISCUSSION}

The complexity of the academic work in an increasingly demanding environment has made academics to effectively manage their work, personal development, and family. With this line of reasoning, this study was conducted to examine social support, negative affectivity, and work-personal life balance of academics at one public higher educational institution in Perak, Malaysia.

The results of this study showed that the correlation between overall social support and work-personal life balance was significant, positive, and moderate. This is consistent with [5], [6], [13], and [14] study. This indicates that social support from supervisor and co-workers can help academics cope with job stressors. Without sufficient support from co-workers and supervisors, academics would experience unnecessary pressures which may lead to stress and low work productivity. With regard to the relationship between work-personal life balance and negative affectivity, results indicated that the relationship between the two was significant, positive, and moderate. This result is similar to those of [9], [15], [16], and [17] study. This means that personality or trait variables influence work-personal life balance. In addition, results of the present study revealed that social support from co-workers was the most important predictor for personal-work life balance. This is similar to result of the study by [17]. This finding suggests that social support from co-workers is important in reducing stress at the workplace and outside of work. Therefore, support from co-workers is important because it can alleviate stress faced by academics, especially when the academic profession is becoming more challenging with academics being burdened 
with a wide range of responsibilities and greater workload demand. At the same time, support from co-workers can help them maintain their work-personal life balance effectively. Likewise organizational leaders in the university must also emphasize greater teamwork within and across organizational units to provide employees with access to support from co-workers in coping with work demands.

\section{CONCLUSION}

Work-personal life balance has become an important topic of discussion among organizational employees. As the academic profession at the university are becoming more challenging and demanding, university management must cooperate in trying to meet the expectations of their academics for achieving a fair balance between work and their personal lives. For instance, university management and educational leaders need to implement consistent policies and practices to ensure that workloads are fairly and equitably distributed among their academics. Management should also provide support for staff training, development, and empowerment opportunities for employees at all levels. Management should also provide adequate resources to enable employees to execute their work tasks efficiently. Thus, organizations with enabling environments produce happy, satisfied, and productive employees which would consequently affect an overall increase in university performance.

\section{REFERENCES}

[1] K. M. Noor, "Work-life balance and intention to leave among academics in Malaysian public higher education institutions," International Journal of Business and Social Science, vol. 2, pp. 240-248, 2011.

[2] C. M. Broers, "Career and family: The role of social support," Ph.D. thesis, University of Griffifth, Brisbane, Australia, 2005.

[3] P. Delecta, "Work-life balance," International Journal of Current Research, vol. 3, no. 4, pp. 186-189, 2011.

[4] S. Susi and K. Jawaharrani, "Work-life balance: The key driver of employee engagement," Asian Journal of Management Research, vol. 2, nol. 1, pp. 474-477, 2010.

[5] C. B. Feldman, E. Brondolo, D. B. Dayan, and J. Schwartz, "Sources of social support and burnout, job satisfaction, and productivity," Journal of Occupational Health Psychology, vol. 7, no. 1, p. 84, 2002.

[6] E. A. Bardoel, "The provision of formal and informal work-practices: The relative importance of institutional and resource dependent explanation versus managerial explanations," Women in Management Review, vol. 18, pp. 7-19, 2003

[7] J. G. Grzywacz and N. F. Marks, "Reconceptualizing the work-family interface: An ecological perspective on the correlates of positive and negative spillover between work and family," Journal of Occupational Health Psychology, vol. 5, no. 1, pp. 111-126, 2000

[8] A. Tellegen, "Development and validation of brief measures of positive and negative affect: The panas scales," Journal of Personality and Social Psychology, vol. 54, no. 6, pp. 163-170, 1998.

[9] A. Z. Stoeva, R. K. Chiu, and J. H. Greenhaus, "Negative affectivity, role stress, and work-family conflict," Journal of Vocational Behaviour, vol. 60, no. 1, pp. 1-16, 2002.

[10] S. Hagargi, "Work-life blanace in Indian ITES/BPO'S," Research Paper Management, vol. 2, no. 6, pp. 157-159, 2013.

[11] K. Saeed and Y. A. Farooqi, "Examining the relationship between work life balance, job stress, and job satisfaction among university teachers (A case of University of Gujarat)," International Journal of Multidisciplinary Sciences and Engineering, vol. 5, no. 6, pp. 9-14, 2014.

[12] C. Qayuum, "Job satisfaction of university teachers across demographics: A case of Pakistani teachers," Bulletin of Education and Research, vol. 35, no. 1, pp. 1-15, 2013.
[13] T. R. Nielson, D. S. Carlson, and M. J. Lankau, "The supportive mentor as a means of reducing work-family conflict," Journal of Vocational Behaviour, vol. 59, pp. 364-381, 2001.

[14] A. Elfering, N. K. Semmer, V. Schade, S. Grund, and N. Boos, "Supportive colleague, unsupportive supervisor: The role of provider-specific constellations of social support at work in the development of low back pain," Journal of Occupational Health Psychology, vol. 7, no. 2, p. 130, 2002.

[15] J. H. Sarah. (2010). Positive and negative affectivity, work stress, job satisfaction and work behaviours. Master's thesis. Central Connecticut. State University. New Britain, Connecticut. [Online]. Available: http://www.content.library.ccsu.edu./cdm/ref/

[16] G. J. Fogarty, M. M. Anthony, M. J. Albion, L. F. Sutherland, G. I Lalor, and S. Revitt, "Predicting occupational strain and job satisfaction: The role of stress, coping, personality, and affectivity variables," Journal of Vocational Behaviour, vol. 54, no. 3, pp. 429-452, 1999.

[17] L. T. Podratz, "The nature of work-personal life balance," Ph.D. dissertation, University of Houston, Texas, USA, 2004.

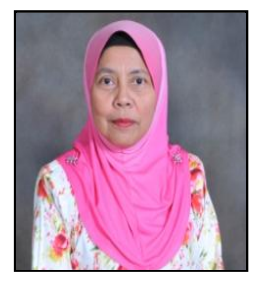

Siti Asiah Md. Shahid obtained a diploma in stenography from Institute Technology Mara, Dungun, Terengganu, Malaysia in 1986. In 1995, she obtained her bachelor of education from the University of Toledo, Toledo, Ohio, USA, majoring in business education. She then pursued her MSc in Education of Virginia Polytechnic Institute and State University, Blacksburg, Virginia, USA, in 1997 and graduated as a major in vocational and technical education. Finally she obtained her PhD in 2011 from University Science Malaysia, Penang, Malaysia, in educational leadership and management. She is a senior lecturer with the Centre of Administration and management in the Faculty of Business Management, University Technology Mara (UiTM) and currently serves as head of professional and enterprise development, institute of business excellence, University Technology Mara Shah Alam, Malaysia. She has also served as head of institute education development of this institution. She has taught business management subjects including administrative office management, human resource management, performance management, organizational communication, and organizational behaviour and has served this institution for 28 years. She has written and presented papers on leadership, soft skills, emotional intelligence, and management. Current research includes social support, negative affectivity, and work personal life balance of academics. Her research fields include leadership soft skills; Soft skills in higher education; Emotional intelligence; Quality of work life; Organizational behaviour; Business and office management and human resource management. Dr. Siti Asiah Md. Shahid has also participated in Innovation, Invention, Design Competition. She leads a project entitled "Towards a New Holistic Leadership Model and won a gold medal award for her participation. She is a lifetime member of Golden Key National Honor Society, USA, a member of Mara Institute of technology academic staff association (MITASA), Malaysia, and also a member of PEWANI (Women association Universiti Teknologi Mara)

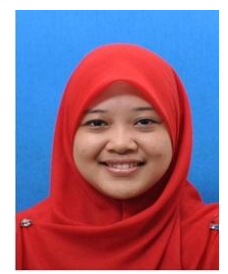

Suhaiel Amdan obtained a bachelor's degree in office system management from University Technology Mara Perak, Malaysia in 2014. Prior to that she obtained a diploma in office management from University Technology Mara Perak, Malaysia in 2012 Currently, she is pursuing her master's degree in office systems management in University Technology Mara Shah Alam, Selangor, Malaysia. She was involved with the Student Career and Counselling Unit in University Technology Mara Perak; Welfare committee of University Technology Mara Perak; She was a member of the Special Tasks Bureau of Leadership and Career Development. Her current research is on working environment, extrinsic motivation, and organizational commitment.

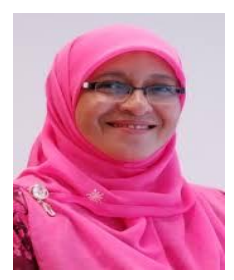

Anisah Alwi obtained a master of education from the University of Nebraska, Lincoln, Nebraska, USA in 1993. She also holds a bachelor of science in education degree from University of Nevada, Reno, Nevada, USA in 1990. Prior to that, in 1980, she earned her diploma in stenography from Institute Technology Mara. Curently, she is pursuing her doctoral degree in the Faculty of Business Management, Universiti Teknologi Mara in the area of Leadership,

Organizational Commitment, Quality of Worklife and Job Characteristics She is currently a senior lecturer with the Centre of Technology Management 
and Supply Chain in the Faculty of Business Management, Universiti Teknologi Mara (UiTM). She has worked with UiTM for the past 26 years. She has also held several administrative posts including examination coordinator and coordinator for out-campus studies and diploma program in UiTM.

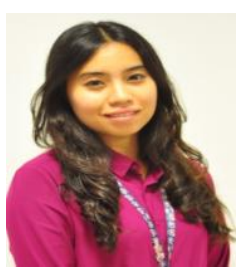

Farah Syazreena Azmi holds a master in office systems management from University Technology Mara Shah Alam, Malaysia in 2012. She also holds a bachelor in office systems management from University Technology Mara Shah Alam, Malaysia, majoring in human resource in 2009. Prior to that she obtained her diploma in office management and technology from Universiti Technology Mara Perak, Malaysia. Currently she is a lecturer at the Faculty of Business Management, University Technology Mara Puncak Alam, Selangor, Malaysia. She has taught several courses in business management including administrative communication for professionals, advanced end user applications, administrative and personnel management, information and communication technologies in organizations and project management. Her current research includes a study on the influence of job stress and job performance in shared service centre industry in Kuala Lumpur, Malaysia.

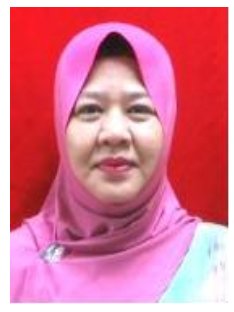

Che Norlia Hassan obtained her bachelor degree in workforce education and development from the Southern Illinois University, Carbondale, USA in 1995 and obtained her master degree in the same field in 1996 from the same university. Prior to that she was awarded a diploma in stenography from Institute Technology Mara in 1984. She completed her doctoral degree in the Faculty of Education, University Science Malaysia, Penang, Malaysia, in the area of soft skills in 2014. She is a senior lecture with the Centre of Administration and Management in the Faculty of Business Management, University Technology Mara (UiTM). She has worked with UiTM for the past 27 years. Her research interests include soft skills, emotional intelligence, quality of work life, and administration and management. 